\title{
Effect of High Concentrate Corn Stalk Particle Size on Physical State and Production Performance of Lactating Dairy Cows
}

\author{
Xueyan Lin', Deqing Zhang², Lin Ju¹, Yiyao Zhang1, Yue Jiang1, Qiuling Hou', Zhiyong Hu1, \\ Yun Wang1, Zhonghua Wang ${ }^{1}$
}

${ }^{1}$ College of Animal Science, Shandong Agricultural University, Tai'an, China

${ }^{2}$ Clinical Reproductive Laboratory, Taian City Central Hospital, Tai'an, China

Email: linxueyan@sdau.edu.cn

How to cite this paper: Lin, X.Y., Zhang, D.Q., Ju, L., Zhang, Y.Y., Jiang, Y., Hou, Q.L., Hu, Z.Y., Wang, Y. and Wang, Z.H. (2021) Effect of High Concentrate Corn Stalk Particle Size on Physical State and Production Performance of Lactating Dairy Cows. Advances in Bioscience and Biotechnology, 12, 45-63.

https://doi.org/10.4236/abb.2021.122004

Received: December 9, 2020

Accepted: February 17, 2021

Published: February 20, 2021

Copyright $\odot 2021$ by author(s) and Scientific Research Publishing Inc. This work is licensed under the Creative Commons Attribution International License (CC BY 4.0).

http://creativecommons.org/licenses/by/4.0/ (c) (i) Open Access

\begin{abstract}
In order to realize the application of corn stalk in cow feed, we designed experiments to explore the effect of a certain proportion of corn stalk on the performance of lactating dairy cows. 9 multiparous mid-lactating cows were allocated at random to three groups, each containing 3 intact cows. The trial consisted of three periods and three dietary treatments with a $3 \times 3$ Latin square design. The diets were normal concentrats plus dried corn stalk chopped to $5-8 \mathrm{~cm}$ long $(\mathrm{N})$, high concentrates plus dried corn stalks chopped to a length of approximately $5-8 \mathrm{~cm}$ by a mower $(\mathrm{H})$ while the milled corn stalks were passed through a pulviser with a $2 \mathrm{~cm}$ pore size $(\mathrm{MH})$. Each cow was measured for dry matter intake (DMI), ruminal $\mathrm{pH}$, rumen fermentation, selective feeding behavior and production performance. The results showed that $\mathrm{MH}$ led to a significantly higher intake of DM, neutral detergent fiber (NDF), forage NDF (FNDF), acid detergent fiber (ADF), crude protein (CP) and organic matter $(\mathrm{OM})$ than $\mathrm{N}$ and $\mathrm{H}(P<0.05)$. Cows fed $\mathrm{H}$ and $\mathrm{MH}$ showed similar selective feeding behavior, while those fed $\mathrm{H}$ showed various selectivity for the dietary component. MH resulted in a significantly higher milk production $(P<0.05)$, and tended to have a higher milk fat production than $\mathrm{N}(P$ $=0.055)$. There were no significant differences in the milk components $(P=$ $0.424)$ and lactose $(P=0.113)$ between cows fed $\mathrm{N}$ and $\mathrm{MH}$. The high-concentrates plus milled corn stalk diet can increase the milk yield under the premise of normal rumen $\mathrm{pH}$ in dairy cows, thereby generating higher economic benefits. And milled corn stalk can effectively inhibit the cow's selective eating of low-quality roughage.
\end{abstract}

\section{Keywords}

Corn Stalk, Lactating Dairy Cow, Production Performance 


\section{Introduction}

Corn stalk is an invaluable resource in agricultural production. The phenomenon of burning corn stover directly in some areas results in air pollution. So the effective utilization of corn stalk resources is conducive to environment protection, resource conservation, and sustainable development of agricultural economy. Compared with alfalfa, corn stalk is much cheaper but a low-quality roughage. For the cost reason, some dairy farms increase the use of corn stover to reduce the use of Alfalfa in TMR. Concentrates are often over used to increase production performance, which leads to subacute rumen acidosis. Previous studies have shown that roughage source and particle size have an impact on dairy performance by affecting dry matter intake (DMI) and the digestibility of nutrients [1] [2].

Roughage intake is mainly regulated by the digestibility of the roughage itself and the energy level of the entire diet [3] [4]. Therefore, when low-quality roughage is used to replace high-quality roughages, it is necessary to consider improving the digestibility of roughage, and the energy level of the diet.

The digestibility of feed may be affected by the size of roughage particles in the diet. However, there were conflicting reports about the relationship between roughage particle size and feed intake. Several reports showed that reducing roughage particle size increases DMI [5], while other reports suggest that roughage size does not affect DMI [6]. In addition, there was also report indicating that the particle size of dietary roughage and the ratio of the concentrates do affect DMI [7]. We spetaculated that the lower the particle size of the roughage, the faster it will pass through the rumen, the faster the rate of rumen emptying, which stimulates feeding and thus increases feed intake.

Roughage particle size, as well as the roughage source, also affects rumen $\mathrm{pH}$ and fermentation [8] [9] [10]. Low-quality roughages have a lower fermentation speed in rumen, which ameliorates rumen $\mathrm{pH}$ decrease. It is possible to improve DMI, rumen fermentation, and production performance through adjusting dietary fermentable organic matter sources and particle size.

Corn stalk can be used as a roughage. However, it is not preferable due to its low quality. Dairy cows may not select corn stalk offered together with other feed if it is not properly processed. In this study, we explored the application prospect of high concentrate corn stalk particle size in cow production.

\section{Materials and Methods}

\subsection{Animals}

12 Holstein multiparous cows, with an average weight $596 \pm 46 \mathrm{~kg}$ and milked $98 \pm 25$ days, were assigned to three groups. Each group contained three intact cows and another one cow with a rumen fistula. Each cow was kept in a separate pen and fed at 06:00 and 18:30 every day, allowing free access to feed. The remaining feed were controlled at about $10 \%$. The cows were milked at 04:30 and 16:30 every day in the milking parlor. Drinking water was supplied 24 hours a 
day.

The animal procedures were approved by the Animal Care and Use Committee of Shandong Agricultural University (Permit number: 20010510), and performed according to the "Guidelines for Experimental Animals" of the Ministry of Science and Technology (Beijing, China).

\subsection{Trial Design}

The entire trial lasted 63 days, divided into 3 periods. Each periods consisted of 15 days of adaptation period and 6 days of sampling period. The fistulated cows were used for the subsequent rumen $\mathrm{pH}$ measurement. The trial was conducted at Qingdao Aote Dairy Farm under the Qingdao Animal Husbandry Research Institute.

\subsection{Diet}

Table 1 shows the test diet ingredients and nutrient composition. Three diets

Table 1. Ingredients and chemical composition of the diets.

\begin{tabular}{|c|c|c|c|}
\hline \multirow{2}{*}{ Item } & \multicolumn{3}{|c|}{ Treatment } \\
\hline & $\mathrm{N}$ & $\mathrm{H}$ & MH \\
\hline \multicolumn{4}{|l|}{ Ingredients (\% DM) } \\
\hline Corn meal & 24.43 & 22.60 & 22.60 \\
\hline Wheat bran & 3.65 & 12.77 & 12.77 \\
\hline Soybean meal & 12.78 & 16.61 & 16.61 \\
\hline Alfalfa hay & 20.07 & 3.50 & 3.50 \\
\hline Oaten hay & 7.12 & 2.53 & 2.53 \\
\hline Corn silage & 22.66 & 20.75 & 20.75 \\
\hline Corn stover & 6.13 & 17.94 & - \\
\hline Corn straw powder & - & - & 17.94 \\
\hline${ }^{1}$ Premix & 3.16 & 3.30 & 3.30 \\
\hline \multicolumn{4}{|c|}{ Chemical composition (\% DM) } \\
\hline${ }^{2} \mathrm{CP}$ & 15.43 & 15.64 & 15.64 \\
\hline${ }^{3} \mathrm{NDF}$ & 36.93 & 40.23 & 40.23 \\
\hline${ }^{4} \mathrm{FNDF}$ & 30.42 & 29.23 & 29.23 \\
\hline${ }^{5} \mathrm{NFC}$ & 36.52 & 32.35 & 32.35 \\
\hline${ }^{6} \mathrm{ADF}$ & 22.33 & 24.45 & 24.45 \\
\hline${ }^{7} \mathrm{FOM}$ & 25.05 & 24.62 & 24.62 \\
\hline${ }^{8} \mathrm{NEL}(\mathrm{MJ} / \mathrm{kg})$ & 1.54 & 1.59 & 1.59 \\
\hline${ }^{9} \mathrm{C}: \mathrm{F}$ & $45: 55$ & $55: 45$ & $55: 45$ \\
\hline
\end{tabular}

Note: ${ }^{1}$ pre-mix contains: VA, $160 \mathrm{KIU} / \mathrm{kg}$; VD3, $30 \mathrm{KIU} / \mathrm{kg}$; VE, $300 \mathrm{mg} / \mathrm{kg}$; Vk3, 30 mg/kg; P, 80 mg/kg; Mn, 550 mg/kg; Zn, 750 mg/kg; Salt, 80 mg/kg; Ca, 200 mg/kg; Cu, 400 mg/kg; Fe, 1800 mg/kg. ${ }^{2} \mathrm{CP}$ : Crude protein; ${ }^{3} \mathrm{NDF}$ : Neutral detergent fiber; ${ }^{4} \mathrm{FNDF}$ : Forage NDF; ${ }^{5} \mathrm{NFC}=100-(\% \mathrm{NDF}+\% \mathrm{CP}+\% \mathrm{EE}$ $+\%$ Ash); ${ }^{6} \mathrm{ADF}$ : Acid detergent fiber; ${ }^{7} \mathrm{FOM}$ : Fermenting organic matter; ${ }^{8} \mathrm{NEL}$ : Net energy for lactation; ${ }^{9} \mathrm{C}$ :F: Ratio of concentrate to forage. 
were used in this trial: normal concentrats plus dried corn stover chopped to 5 $8 \mathrm{~cm}$ long $(\mathrm{N})$, high concentrates plus dried corn stover chopped to $5-8 \mathrm{~cm}$ long $(\mathrm{H})$, and high concentrates plus milled corn stover passed through a screen of $2 \mathrm{~cm}$ pore size $(\mathrm{MH}) . \mathrm{H}$ and $\mathrm{MH}$ have the same ingredient ratio, but differ in the way by which corn stalk was processed. The corn stalk in $\mathrm{H}$ was cut into 5 - 8 $\mathrm{cm}$ long pieces with a chaff cutter, while in $\mathrm{MH}$, it is milled and passed through a screen of $2-\mathrm{cm}$ pore size. The parameters of stalk crusher are as follows: mill rotation speed is $2800 \mathrm{r} / \mathrm{min}$, the speed of the motor output shaft is $1460 \mathrm{r} / \mathrm{min}$, the output torque of the motor is $33 \mathrm{Nm}$, the output torque of the motor shaft is $62.8 \mathrm{Nm}$ and that of the cutter shaft is $17.8 \mathrm{Nm}$. The particle size distribution of $2 \mathrm{~cm}$ corn stalk is $14.57 \% \mathrm{DM}$. The diets were designed to have the some levels of fermentable organic matter, energy and protein. In addition, mineral licks bricks were placed between every two test cows during the trial to ensure the needs for minerals throughout the trial.

\subsection{Sample Collection}

\subsubsection{Nutrient Intake}

On the 17th to 19th day of each period, the amounts of feed supplied per cow per day were recorded and the amount of remains was recorded before feeding the next morning. Feed and remains were collected after respectively mixed to uniform. Samples were dried in a ventilated electric oven at $65^{\circ} \mathrm{C}$. The loss moisture of each sample was measured and recorded after dried to a constant weight. After drying, the material was pulverized, and passed through a 1-mm screen. The comminuted feed was placed in Ziplock bags and sealed and stored in a $-20^{\circ} \mathrm{C}$ freezer until determination of the various nutrient contents.

\subsubsection{Particle Size Distribution and Selective Feeding Behavior}

On the 16th day of each period, mix feed at 4-hour intervals $(0,4,8,12 \mathrm{~h})$ after feed offering and collected remaining forage (500 g each) after each mixing. The orts were immediately separated using a Penn State Particle Separator (PSPS), measured for $\mathrm{DM}$ in an oven at $105^{\circ} \mathrm{C}$, observe the changes of sample proportion to analyzed selective behavior and calculate peNDF content.

\subsubsection{Apparent Nutrient Digestibility}

On the 19th day of each period, the fecal samples were collected from the rectum every 6 hours $(6: 00,12: 00,18: 00,24: 00)$ after morning feeding (6:00) for a total of 4 times. The fecal samples collected at each time point of each cow were mixed in equal proportions during each test period. Various nutrients in feed such as dry matter (DM), crude protein (CP), neutral detergent fiber (NDF), acid detergent fiber (ADF), total energy (GE) and Ash (Ash) were measured.

\subsubsection{Milk Yield and Composition}

On the 17th to 19th day of each period, milk yield per cow per day was recorded. In addition, milk samples were also collected and mixed during the milking time twice a day. Preservative potassium dichromate was added to each bottle of milk 
and kept at $-4^{\circ} \mathrm{C}$ using an ice pack. The milk samples were sent to Jinan Dairy DHI Measurement Center on the same day, and measured for fat, protein, lactose, total solids (TS), and urea nitrogen in milk.

\subsubsection{Chewing Activity}

On the 17th and 18th day of each period, each cow was recorded for 48 hours using video surveillance equipment. The obtained video file was first saved in the hard disk recorder and then stored using a mobile storage device. The chewing activity was mannually assessed through video playback. The feeding time and ruminating time of each cow were accurately recorded. A single feeding time is defined as the cow ingests feed for more than 7 minutes continuously and maintained no feed intake for at least 7 minutes before the next intake. Similarly, a ruminating time is defined as the ruminating lasts for more than 5 minutes, and without rumination for at least 5 minutes [11]. The daily chewing time is defined as the daily feeding time plus the daily ruminating time.

\subsubsection{Ruminal $\mathrm{pH}$ and VFA}

Rumen $\mathrm{pH}$ was recorded on the 19th and 20th day of each period at 5 minutes interval. The rumen $\mathrm{pH}$ recorder (DASCOR LRC $\mathrm{pH}$, Canada) was placed in the bottom of the rumen through the fistula after loading the $\mathrm{pH}$ meter with weight (preventing the rumen $\mathrm{pH}$ recorder from moving in the rumen due to rumen motility, keeping the rumen $\mathrm{pH}$ recorder position relatively fixed). On the 20th day of each period, rumen fluid was collected from multiple sites (front, back, anterior, posterior, and medial) at $0,2,4,6$ and $8 \mathrm{~h}$ post morning feeding. The sample was filtered through 4 layers of gauze. A sample of $5 \mathrm{ml}$ rumen fluid was mixed with $1 \mathrm{ml}$ of $25 \%$ (wt/vol) $\mathrm{HPO}_{3}$ and stored at $-20^{\circ} \mathrm{C}$ for the determination of VFA. Another ruminal fluid sample of $5 \mathrm{ml}$ was mixed with $1 \mathrm{ml}$ of $1 \%$ $\mathrm{H}_{2} \mathrm{SO}_{4}$ and stored at $-20^{\circ} \mathrm{C}$ for determination of $\mathrm{NH}_{3}-\mathrm{N}$ concentration.

\subsubsection{Serum Parameter}

Serum samples were taken on the 21 st day of each period. The cows were standing to collect blood through the jugular vein between milking and morning feeding. The collected blood was immediately incubated at $37^{\circ} \mathrm{C}$ for $60 \mathrm{~min}$, then centrifuged for $3 \mathrm{~min}$ at $3500 \mathrm{rpm}$ to separate serum. Serum was dispensed and stored in a $1.5-\mathrm{ml}$ centrifuge tube at $-20^{\circ} \mathrm{C}$ until the following biochemical indicators such as insulin (Ins), glucagon (GCG), growth hormone (HGH), serotonin (5-HT), non-esterified fatty acids (NEFA), leptin (LEP), insulin-like growth factor-1 (IGF-1), glucagon-like peptide 1 (GLP-1), cortisol (FC), free fatty acid, volatile fatty acid (VFA), and $\beta$-hydroxybutyric acid $(\beta$-HB).

\subsection{Determination Methods}

The DM in the diet, orts and faeces was determined with the AOAC (1990) method, and the CP content was determined with the Kjeldahl method. Ash in the diet, orts, and feces was determined after burning in a muffle furnace at $550^{\circ} \mathrm{C}$ overnight. The OM content in the diet, ort and feces were DM content minus 
Ash content. The determination of NDF and ADF in diets, orts and fecal samples was based on the method of Van Soest et al.. The GE in the diet, residual feed, and feces was measured using a fully automated oxygen bomb calorimeter (Parr 6200, USA). The starch content in diets, orts and feces was determined using the Anthrone method (1999). Milk composition was analyzed using a near infrared milk composition analyzer (Foss-4000; Foss Electric, Hillerød, Denmark). VFA was measured according to the method described by Yang and Varga (1989). $\mathrm{NH}_{3}-\mathrm{N}$ was measured with the method by Weatherburn (1967).

The particle size distribution of the diet was determined with a PSPS. The PSPS consists of four layers, $19 \mathrm{~mm}, 8 \mathrm{~mm}, 4 \mathrm{~mm}$ and chassis. The value of pef 4.0 was the ratio between the sum of DM in two layers $(19 \mathrm{~mm}$ and $8 \mathrm{~mm}$ ) and the total DM. The value of pef 8.0 is the ratio between the sum of DM in three layers $(19 \mathrm{~mm}, 8 \mathrm{~mm}$ and $4 \mathrm{~mm}$ ) and the total DM. The content of peNDF $>4$ $\mathrm{mm}$ and peNDF $>8 \mathrm{~mm}$ was the product of pef 4.0 and pef 8.0 and dietary NDF content, respectively.

Serum biochemical parameters were determined using an automated biochemical analyzer (Hitachi, type: 7020). The serum $\beta$-hydroxybutyric acid (BHBA) and non-esterified fatty acid (NEFA) kits were produced by Nanjing Jiancheng Biotechnology Co., Ltd. Serum insulin, glucagon, and insulin-like growth factor-1 (IGF-1) were determined by radioactive immunoassay from Taian Central Hospital (the radioimmunoassay kit was purchased from Tianjin Jiuding). Leptin, glucagon-like peptide 1 (GLP-1), and serotonin (5-HT) were determined with a cow serum hormone ELISA kit purchased from Shanghai Xinran Reagent Co., Ltd.

\subsection{Data Analysis}

All data were analyzed for variance using the SAS 9.1 software MIXED procedure. The model for analysis of nutrient intake, nutrient apparent digestibility, dietary grain size, selective behavior, blood index, milk yield and milk composition was:

$$
Y=\mu+S_{i}+C_{j(i)}+P_{k}+T_{l}+(P \times T)_{k l}+e_{i j k l}
$$

where: $\mu=$ population mean; $S_{i}=$ Latin square random effect ( $i=1$ to 3$) ; C_{f^{(i)}}=$ cattle random effect $(j=1$ to 4$) ; P_{k}=$ period fixed effect $(k=1$ to 4$) ; T_{I}=$ fixed effects $(I=1$ to 4$) ;(P \times T)_{k l}=$ period and process interaction fixed effects; $e_{i j k l}=$ random residuals.

Chewing activities were summarized on a daily basis and analyzed using the REPEATED statement. The statistical model is as follows:

$$
Y=\mu+S_{i}+C_{j(i)}+P_{k}+T_{l}+(P \times T)_{k l}+D_{m}+e_{i j k l m}
$$

where: $\mu=$ population mean; $S_{i}=$ Latin square random effect ( $i=1$ to 3$) ; C_{f^{(i)}}=$ cow random effect ( $j=1$ to 4$) ; P_{k}=$ period fixed effect ( $k=1$ to 4$) ; T_{I}=$ fixed effects $(I=1$ to 4$) ;(P \times T)_{k l}=$ period and process interaction fixed effects; $D_{m}=$ days as repeated fixed effects; $e_{i j k l}=$ random residuals. 
The rumen $\mathrm{pH}$ and VFA model was:

$$
Y=\mu+C_{i}+P_{j}+T_{k}+e_{i j k}
$$

where: $\mu=$ population mean; $C_{i}=$ cattle random effect $(i=1$ to 4$) ; P_{j}=$ period fixed effect ( $j=1$ to 4$) ; T_{k}=$ treatment fixed effect $(k=1$ to 4$) ; e_{i j k}=$ random residuals. All data were presented as the least square mean. The linear, quadratic curve and cubic curves of indices as a function of roughage level were implemented using the CONTRAST statement. Correlation analysis was performed using the CORR process. $P<0.05$ indicates that the effect is significant, and 0.05 $<P<0.1$ indicates an influential trend.

\section{Results}

\subsection{Particle Size Distribution, pef and peNDF Content}

Table 2 shows the particle size distribution, physical effectiveness factor (pef) and physically effective neutral detergent fiber (peNDF) content of each diet. As seen from the table, there were significant differences among different diets in the ratio of $19 \mathrm{~mm}$ component and the bottom pan component $(P<0.05)$, significantly decreased in the $\mathrm{MH}(P<0.05) . \mathrm{H}$ and $\mathrm{MH}$ had a significantly higher ratio of the bottom pan component compared with $\mathrm{N}(P<0.01)$. There was no effect on the ratio of $8 \mathrm{~mm}$ and $4 \mathrm{~mm}$ components. This result is caused by the difference in the ratio of the roughages to the concentrates in the three diets, and the difference in particle size of the corn stalk between $\mathrm{H}$ and $\mathrm{MH}$. Since $\mathrm{H}$ had a higher concentrate content, it had a higher proportion at the bottom pan component. In contrast, $\mathrm{MH}$ used pulverized corn stalk, thus had further increased the proportion of the bottom pan component in the diet. As a result, the proportion

Table 2. Particle size distribution, physical effectiveness factors (pef), and physically effective neutral detergent fiber (peNDF) contents of the diets.

\begin{tabular}{cccccc}
\hline & \multicolumn{5}{c}{ Treatment $^{1}$} \\
Item & $\mathrm{N}$ & $\mathrm{H}$ & $\mathrm{MH}$ & & \\
\cline { 2 - 3 } & & SEM & $P^{2}$-value \\
\hline \multirow{2}{*}{$19 \mathrm{~mm}$} & $32.76 \mathrm{a}$ & $20.17 \mathrm{~b}$ & $12.84 \mathrm{c}$ & 1.259 & $<0.001$ \\
$8 \mathrm{~mm}$ & 22.21 & 22.86 & 22.10 & 1.169 & 0.855 \\
$4 \mathrm{~mm}$ & 14.21 & 14.27 & 15.76 & 0.652 & 0.179 \\
Pan & $30.82 \mathrm{c}$ & $42.70 \mathrm{~b}$ & $49.30 \mathrm{a}$ & 1.804 & $<0.001$ \\
pef4.0 & $0.69 \mathrm{a}$ & $0.57 \mathrm{~b}$ & $0.51 \mathrm{c}$ & 0.018 & $<0.001$ \\
pef8.0 & $0.55 \mathrm{a}$ & $0.43 \mathrm{~b}$ & $0.35 \mathrm{c}$ & 0.016 & $<0.001$ \\
peNDF $>4 \mathrm{~mm}$ & $25.55 \mathrm{a}$ & $23.05 \mathrm{~b}$ & $20.40 \mathrm{c}$ & 0.702 & $<0.001$ \\
peNDF $>8 \mathrm{~mm}$ & $20.30 \mathrm{a}$ & $17.31 \mathrm{~b}$ & $14.05 \mathrm{c}$ & 0.608 & $<0.001$ \\
\hline
\end{tabular}

Note: ${ }^{1} \mathrm{~N}$ control diet, $\mathrm{H}$ : corn stover high concentrates diet, $\mathrm{MH}$ : milled corn stover high concentrates diet. ${ }^{2} P>0.05$ indicating no significant effect, $P<0.05$ indicating significant effect, $0.05<P<0.10$ indicating a tendency of effect. Values within a row followed by different letters are significantly different (at $P=0.05$ ). PSPS: Pennsylvania filter. Pan: pef: Physical efficiency coefficient. peNDF: Physically effective factor NDF. 
of the $19 \mathrm{~mm}$ component was decreased sequentially in $\mathrm{H}$ and $\mathrm{MH}$ compared with $\mathrm{N}$, while the proportion of the bottom pan component was increased. The diets significantly affected pef 4.0 , pef 8.0 , peNDF $>4 \mathrm{~mm}$ and peNDF $>8 \mathrm{~mm}$ $(P<0.05)$. This result was similar to the ratio of dietary layers.

\subsection{Nutrient Intake and Apparent Digestibility of Each Diet}

As shown in Table 3, the intakes of DM, NDF, FNDF, ADF, CP and OM were significantly higher when cows were fed $\mathrm{MH}$ than those when cows were fed $\mathrm{N}$ and $\mathrm{H}(P<0.05)$. The differences in peNDF $>4 \mathrm{~mm}$ among diets were not significant. Regarding peNDF $>8 \mathrm{~mm}, \mathrm{~N}$ was significantly higher than $\mathrm{H}$ and $\mathrm{MH}$ $(P<0.05)$.

There were significant differences among the three diets in CP digestibility $(P$ $<0.05)$. $\mathrm{N}$ had the highest $\mathrm{CP}$ digestibility, while $\mathrm{MH}$ had the lowest. $\mathrm{H}$ and $\mathrm{MH}$ had significantly higher digestibility of NDF and ADF $(P<0.05)$. There were also significant differences among the three in $\mathrm{OM}(P<0.05)$, where $\mathrm{N}$ had the highest OM digestibility.

\subsection{Cumulative Selective Behavior under Different Diets}

As shown in Table 4, except cows fed $\mathrm{N}$, those fed other diets showed selective

Table 3. Effects of the diets on dietary nutrients intake and apparent digestibility in lactating Holstein cows.

\begin{tabular}{|c|c|c|c|c|c|}
\hline \multirow{2}{*}{ Item } & \multicolumn{3}{|c|}{ Treatment $^{1}$} & \multirow[b]{2}{*}{ SEM } & \multirow[b]{2}{*}{$P^{2}$-value } \\
\hline & $\mathrm{N}$ & $\mathrm{H}$ & $\mathrm{MH}$ & & \\
\hline \multicolumn{6}{|c|}{ Intake of nutriment $(\mathrm{kg} / \mathrm{d})$} \\
\hline $\mathrm{DM}$ & $19.91 b$ & $20.16 \mathrm{~b}$ & $22.40 \mathrm{a}$ & 1.095 & $<0.001$ \\
\hline $\mathrm{NDF}$ & $6.78 \mathrm{~b}$ & $7.31 \mathrm{~b}$ & $10.51 \mathrm{a}$ & 0.462 & $<0.001$ \\
\hline FNDF & $6.06 \mathrm{~b}$ & $5.89 \mathrm{~b}$ & $6.55 \mathrm{a}$ & 0.324 & 0.002 \\
\hline peNDF $>4 \mathrm{~mm}$ & 5.10 & 4.62 & 4.56 & 0.293 & 0.148 \\
\hline peNDF $>8 \mathrm{~mm}$ & $4.04 \mathrm{a}$ & $3.49 \mathrm{~b}$ & $3.13 b$ & 0.223 & 0.005 \\
\hline $\mathrm{ADF}$ & $3.71 \mathrm{~b}$ & $3.65 \mathrm{~b}$ & $4.95 \mathrm{a}$ & 0.231 & $<0.001$ \\
\hline $\mathrm{CP}$ & $3.16 \mathrm{~b}$ & $3.28 \mathrm{~b}$ & $3.57 \mathrm{a}$ & 0.175 & $<0.001$ \\
\hline $\mathrm{OM}$ & $18.34 \mathrm{~b}$ & $18.33 \mathrm{~b}$ & $20.53 a$ & 1.000 & $<0.001$ \\
\hline \multicolumn{6}{|c|}{ Apparent digestibility (\%) } \\
\hline $\mathrm{DM}$ & $56.93 \mathrm{ab}$ & $55.04 \mathrm{~b}$ & $59.11 \mathrm{a}$ & 1.310 & 0.058 \\
\hline $\mathrm{NDF}$ & $41.53 \mathrm{~b}$ & $41.05 \mathrm{~b}$ & $51.61 \mathrm{a}$ & 0.772 & $<0.001$ \\
\hline $\mathrm{ADF}$ & $37.05 b$ & $41.48 \mathrm{a}$ & $39.61 \mathrm{a}$ & 0.736 & 0.001 \\
\hline $\mathrm{CP}$ & $65.71 \mathrm{a}$ & $59.24 \mathrm{c}$ & $62.27 \mathrm{~b}$ & 1.421 & $<0.001$ \\
\hline OM & $65.00 \mathrm{a}$ & $59.24 \mathrm{c}$ & $62.27 \mathrm{~b}$ & 1.076 & $<0.001$ \\
\hline
\end{tabular}

Note: ${ }^{1} \mathrm{~N}$ control diet, $\mathrm{H}$ : corn stover high concentrates diet, $\mathrm{MH}$ : milled corn stover high concentrates diet. ${ }^{2} P>0.05$ indicating no significant effect, $P<0.05$ indicating significant effect, $0.05<P<0.10$ indicating a tendency of effect. Values within a row followed by different letters are significantly different (at $P=0.05$ ). 
Table 4. Effects of the diets on cumulative selection indices for various particle fractions in lactating Holstein cows. ${ }^{1}$

\begin{tabular}{|c|c|c|c|c|c|}
\hline \multirow{2}{*}{ Item } & \multicolumn{3}{|c|}{ Treatment $^{2}$} & \multirow[b]{2}{*}{ SEM } & \multirow[b]{2}{*}{$P^{3}$-value } \\
\hline & $\mathrm{N}$ & $\mathrm{H}$ & $\mathrm{MH}$ & & \\
\hline \multicolumn{6}{|l|}{$19 \mathrm{~mm}$} \\
\hline $4 \mathrm{~h}$ & 0.97 & 0.95 & 0.87 & 0.052 & 0.311 \\
\hline $8 \mathrm{~h}$ & 0.95 & 0.95 & 0.94 & 0.026 & 0.827 \\
\hline $12 \mathrm{~h}$ & 1.00 & 0.97 & 0.97 & 0.012 & 0.217 \\
\hline \multicolumn{6}{|l|}{$8 \mathrm{~mm}$} \\
\hline $4 \mathrm{~h}$ & 1.01 & 0.94 & 1.01 & 0.032 & 0.173 \\
\hline $8 \mathrm{~h}$ & 1.03 & 0.98 & 1.01 & 0.021 & 0.180 \\
\hline $12 \mathrm{~h}$ & 1.00 & 1.00 & 1.00 & 0.006 & 0.858 \\
\hline \multicolumn{6}{|l|}{$4 \mathrm{~mm}$} \\
\hline $4 \mathrm{~h}$ & $1.04 \mathrm{a}$ & $0.97 \mathrm{ab}$ & $0.92 \mathrm{~b}$ & 0.035 & 0.069 \\
\hline $8 \mathrm{~h}$ & 1.04 & 0.98 & 1.00 & 0.023 & 0.136 \\
\hline $12 \mathrm{~h}$ & $1.02 \mathrm{a}$ & $1.01 \mathrm{ab}$ & $1.00 \mathrm{~b}$ & 0.007 & 0.032 \\
\hline \multicolumn{6}{|l|}{ Pan } \\
\hline $4 \mathrm{~h}$ & 1.00 & 1.05 & 1.02 & 0.037 & 0.676 \\
\hline $8 \mathrm{~h}$ & 1.01 & 1.03 & 1.00 & 0.020 & 0.494 \\
\hline $12 \mathrm{~h}$ & 1.00 & 1.01 & 1.00 & 0.007 & 0.600 \\
\hline
\end{tabular}

Note: ${ }^{1}$ value $=1.00$ indicating no selective behavior; value $>1.00$ indicating preferred; value $<1.00$ indicating against. ${ }^{2} \mathrm{~N}$ control diet, $\mathrm{H}$ : corn stover high concentrates diet, $\mathrm{MH}$ : milled corn stover high concentrates diet. ${ }^{3} P>0.05$ indicating no significant effect, $P<0.05$ indicating significant effect, $0.05<P<0.10$ indicating a tendency of effect. Values within a row followed by different letters are significantly different (at $P=0.05)$.

behavior over $>19 \mathrm{~mm}$ particles at $12 \mathrm{~h}$. All treatment groups preferred the portion of diet in the bottom pan. Cows fed $\mathrm{H}$ showed various levels of selectivity over particles retained in the screens. Cows fed $\mathrm{MH}$ showed selective behavior over particles retained in the $4 \mathrm{~mm}$ screen, those fed $\mathrm{N}$ and $\mathrm{MH}$ showed similar cumulative selective behavior about particles below the $19-\mathrm{mm}$ screen.

\subsection{Continuous Selective Behavior under Different Diets}

Table 5 shows the effects of diets on the continuous selective behavior of lactating Holstein cattle. Each group showed different levels of continuous selective behavior about different particle size ranges. When fed $\mathrm{H}$, cows displayed selective behavior about $\geq 4 \mathrm{~mm}$ components. Compared with $\mathrm{N}, \mathrm{MH}$ resulted in significantly lower continuous selectivity at $4 \mathrm{~h}$ after morning feeding, and lower selectivity about the bottom pan component $8 \mathrm{~h}$ after feeding.

\subsection{Changes in the Proportion of Components}

As shown in Figure 1, there were various degrees of changes in the proportion 


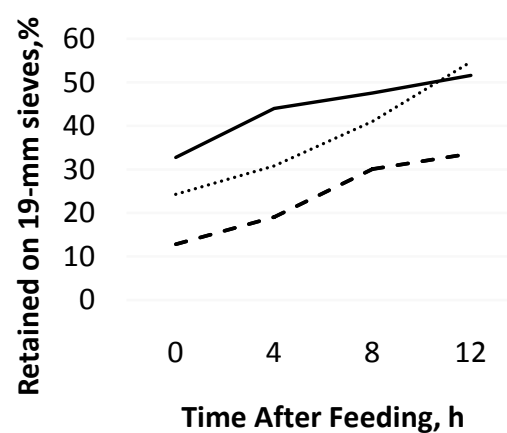

Time After Feeding, $\mathbf{h}$

N

$\mathrm{H}---\mathrm{MH}$

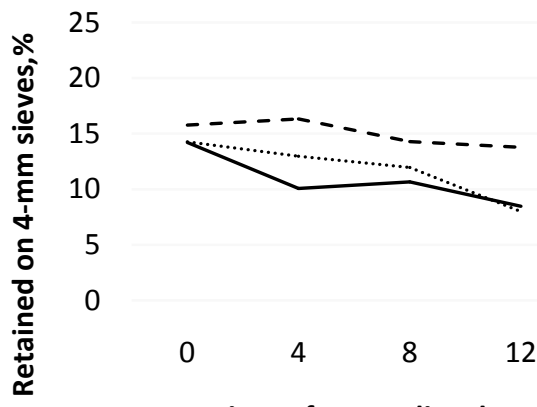

Time After Feeding, $\mathrm{h}$

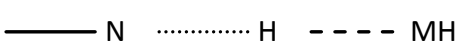

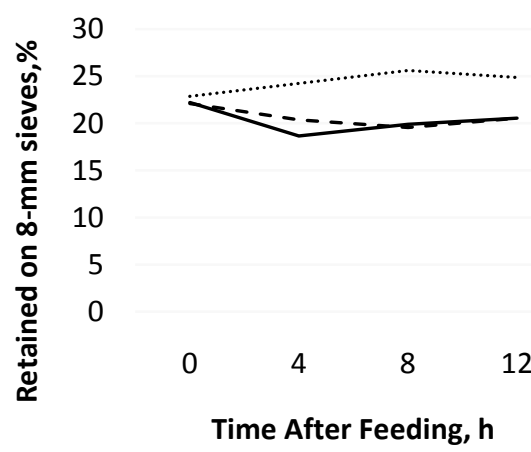

$\mathrm{H}---\mathrm{MH}$
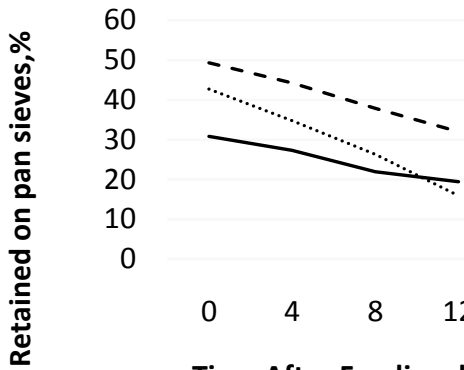

Time After Feeding, $\mathrm{h}$

$\mathrm{H}---\mathrm{MH}$

Figure 1. Effects of the diets on the proportion of four layers after feeding in lactating Holstein cows. $\mathrm{N}$ control diet, $\mathrm{H}$ : corn stover high concentrates diet, $\mathrm{MH}$ : milled corn stover high concentrates diet. Various degrees of changes in the proportion of different sized particles in the orts after feeding in the morning.

Table 5. Effects of diets on interval selection indices for various particle fractions in lactating Holstein cows. ${ }^{1}$

\begin{tabular}{cccccc}
\hline & \multicolumn{5}{c}{ Treatment $^{2}$} \\
Item & $\mathrm{N}$ & $\mathrm{H}$ & $\mathrm{MH}$ & SEM & $P^{3}$-value \\
\cline { 2 - 3 } $19 \mathrm{~mm}$ & & & & & \\
$4 \mathrm{~h}$ & 0.97 & 0.95 & 0.87 & 0.012 & 0.217 \\
$8 \mathrm{~h}$ & 0.92 & 0.93 & 0.93 & 0.050 & 0.976 \\
$12 \mathrm{~h}$ & 0.98 & 0.87 & 0.87 & 0.036 & 0.020 \\
$8 \mathrm{~mm}$ & & & & & \\
$4 \mathrm{~h}$ & 1.01 & 0.94 & 1.01 & 0.032 & 0.173 \\
$8 \mathrm{~h}$ & 1.00 & 0.95 & 1.05 & 0.062 & 0.329 \\
$12 \mathrm{~h}$ & 0.99 & 1.01 & 0.86 & 0.053 & 0.112 \\
$4 \mathrm{~mm}$ & & & & & \\
$4 \mathrm{~h}$ & $1.04 \mathrm{a}$ & $0.97 \mathrm{ab}$ & $0.92 \mathrm{~b}$ & 0.035 & 0.069 \\
$8 \mathrm{~h}$ & 1.14 & 0.93 & 1.04 & 0.080 & 0.120 \\
$12 \mathrm{~h}$ & 1.07 & 1.08 & 0.96 & 0.061 & 0.333 \\
\hline
\end{tabular}


Continued

\begin{tabular}{rlllll}
\hline Pan & & & & & \\
$4 \mathrm{~h}$ & 1.00 & 1.05 & 1.02 & 0.037 & 0.676 \\
$8 \mathrm{~h}$ & 1.08 & 1.13 & 0.98 & 0.066 & 1.185 \\
$12 \mathrm{~h}$ & 1.11 & 1.05 & 1.14 & 0.056 & 0.506 \\
\hline
\end{tabular}

Note: ${ }^{1}$ Value $=1.00$ No selective eating, Value $>1.00$ Like, Value $<1.00$ Dislike. ${ }^{2} \mathrm{~N}$ control diet, H: corn stover high concentrates diet, MH: milled corn stover high concentrates diet. ${ }^{3} P>0.05$ indicating no significant effect, $P<0.05$ indicating significant effect, $0.05<P<0.10$ indicating a tendency of effect. Values within a row followed by different letters are significantly different (at $P=0.05$ ).

of different sized particles in the orts after feeding in the morning. The changes were greatest in the proportion of $19 \mathrm{~mm}$ component, and the bottom pan component, while there was little change in the proportion of $8 \mathrm{~mm}$ and $4 \mathrm{~mm}$ component. The proportion in the $19 \mathrm{~mm}$ component increased along with increasing feeding time, while the proportions of $4 \mathrm{~mm}$ and the bottom pan components decreased along with feeding time increasing. This indicates that cows had different degrees of selective behavior. $\mathrm{H}$ showed greater changes in the proportion of each size range with the increase in time, compared with $\mathrm{MH}$, indicating that the conversion of corn stalk into powder could indeed reduce the selective behavior of dairy cattle.

\subsection{Milk yield and Composition}

As shown in Table 6, cows fed MH produced more milk and 4\%FCM than those fed $\mathrm{H}(P<0.05)$. There were no significant differences in milk protein production, milk fat, milk protein, lactose.

\subsection{Chewing Activity}

A feeding incidence is defined as the continuous feed consumption for at least 7 minutes and maintained no consumption for 7 minutes for a cow. A ruminating incidence is defined as the continuous ruminating for at least 5 minutes and maintained no ruminating for 5 minutes before the next time of rumination [11]. The total chewing time is the sum of feed consumption time and ruminating time. The chewing time per kilogram of DM (or OM, NDF, ADF) is chewing (consumption, ruminating) time over dietary DMI (or OMI, NDFI ADFI). As shown in Table 7, there was no significant difference in the time to consume different diets, but $\mathrm{N}$ and $\mathrm{H}$ needed longer consumption times per kilogram of $\mathrm{DM}, \mathrm{ADF}$, and NDF than $\mathrm{MH}(P<0.05)$.

There was no significant difference in the ruminating time among groups. The ruminating times per kilogram of ADF and NDF for $\mathrm{N}$ and $\mathrm{H}$ were significantly longer than that for $\mathrm{MH}(P<0.05)$, and the ruminating time per kilogram of DM for $\mathrm{N}$ was also significantly longer than that for $\mathrm{MH}(P<0.05)$.

There was also no significant difference in the total chewing time. $\mathrm{N}$ and $\mathrm{H}$ needed significantly longer consumption times per kilogram of DM, ADF, and NDF than MH $(P<0.05)$. 
Table 6. Effects of the diets on the milk yield and composition in lactating Holstein cows.

\begin{tabular}{cccccc}
\hline & \multicolumn{5}{c}{ Treatment $^{1}$} \\
Item & $\mathrm{N}$ & $\mathrm{H}$ & $\mathrm{MH}$ & SEM & $P^{2}$-value \\
\cline { 2 - 3 } Yield (kg/d) & & & & & \\
Milk & $30.37 \mathrm{~b}$ & $30.31 \mathrm{~b}$ & $32.59 \mathrm{a}$ & 1.478 & 0.048 \\
4\% FCM3 & $27.48 \mathrm{~b}$ & $27.54 \mathrm{ab}$ & $30.13 \mathrm{a}$ & 1.483 & 0.105 \\
Fat & 1.02 & 1.02 & 1.14 & 0.067 & 0.126 \\
Protein & 0.94 & 0.85 & 0.91 & 0.071 & 0.307 \\
Lactose & 1.48 & 1.60 & 1.69 & 0.087 & 0.059 \\
Content (\%) & & & & & \\
Fat & 3.39 & 3.33 & 3.49 & 0.135 & 0.830 \\
Protein & 3.09 & 2.75 & 2.87 & 0.19 & 0.435 \\
Lactose & 4.89 & 5.19 & 5.22 & 0.15 & 0.176 \\
Total solid (TS) & 12.31 & 12.22 & 12.38 & 0.21 & 0.800 \\
$\begin{array}{c}\text { Milk urea nitrogen } \\
\text { (MUN) (mg/dl) }\end{array}$ & 14.25 & 15.02 & 15.25 & 1.76 & 0.336 \\
\hline
\end{tabular}

Note: ${ }^{1} \mathrm{~N}$ control diet, $\mathrm{H}$ : corn stover high concentrates diet, $\mathrm{MH}$ : milled corn stover high concentrates diet. ${ }^{2} P>0.05$ indicating no significant effect, $P<0.05$ indicating significant effect, $0.05<P<0.10$ indicating a tendency of effect. Values within a row followed by different letters are significantly different (at $P=0.05$.) $34 \% \mathrm{FCM}=[15 \times$ Fat $(\%)+0.4] \times$ Milk production $(\mathrm{kg} / \mathrm{d})$.

Table 7. Effects of the diets on chewing activity in lactating Holstein cows.

\begin{tabular}{|c|c|c|c|c|c|}
\hline \multirow{2}{*}{ Item } & \multicolumn{3}{|c|}{ Treatment $^{1}$} & \multirow[b]{2}{*}{ SEM } & \multirow[b]{2}{*}{$P^{2}$-value } \\
\hline & $\mathrm{N}$ & $\mathrm{H}$ & MH & & \\
\hline \multicolumn{6}{|l|}{ Eating } \\
\hline $\min / \mathrm{d}$ & 303.33 & 293.33 & 300.83 & 15.111 & 0.487 \\
\hline $\mathrm{Min} / \mathrm{kg}$ of $\mathrm{DM}$ & $15.60 \mathrm{a}$ & $14.69 \mathrm{a}$ & $13.64 \mathrm{~b}$ & 0.793 & 0.001 \\
\hline $\mathrm{Min} / \mathrm{kg}$ of $\mathrm{ADF}$ & $84.53 \mathrm{a}$ & $81.74 a$ & $61.74 b$ & 4.540 & $<0.001$ \\
\hline $\mathrm{Min} / \mathrm{kg}$ of $\mathrm{NDF}$ & $46.16 a$ & $40.96 a$ & $29.03 b$ & 2.340 & $<0.001$ \\
\hline $\mathrm{Min} / \mathrm{kg}$ of FNDF & $51.27 \mathrm{a}$ & $50.25 \mathrm{ab}$ & $46.66 \mathrm{~b}$ & 2.666 & 0.014 \\
\hline $\mathrm{Min} / \mathrm{kg}$ of $\mathrm{peNDF}>4 \mathrm{~mm}$ & 62.50 & 64.82 & 69.08 & 4.462 & 0.365 \\
\hline $\mathrm{Min} / \mathrm{kg}$ of $\mathrm{peNDF}>8 \mathrm{~mm}$ & $78.81 b$ & $86.64 \mathrm{ab}$ & $101.39 \mathrm{a}$ & 6.707 & 0.026 \\
\hline \multicolumn{6}{|l|}{ Ruminating } \\
\hline $\min / \mathrm{d}$ & 471.67 & 472.92 & 472.08 & 20.494 & 0.998 \\
\hline $\mathrm{Min} / \mathrm{kg}$ of DM & $24.43 \mathrm{a}$ & $23.93 \mathrm{ab}$ & $21.58 \mathrm{~b}$ & 1.358 & 0.044 \\
\hline $\mathrm{Min} / \mathrm{kg}$ of $\mathrm{ADF}$ & $132.49 a$ & $133.56 a$ & $97.44 \mathrm{~b}$ & 8.000 & $<0.001$ \\
\hline $\mathrm{Min} / \mathrm{kg}$ of NDF & $72.51 \mathrm{a}$ & $66.91 \mathrm{a}$ & $45.83 b$ & 4.200 & $<0.001$ \\
\hline $\mathrm{Min} / \mathrm{kg}$ of FNDF & $80.30 \mathrm{ab}$ & $81.88 \mathrm{a}$ & $73.82 b$ & 4.549 & 0.097 \\
\hline $\mathrm{Min} / \mathrm{kg}$ of $\mathrm{peNDF}>4 \mathrm{~mm}$ & 98.06 & 104.90 & 107.43 & 6.951 & 0.502 \\
\hline $\mathrm{Min} / \mathrm{kg}$ of $\mathrm{peNDF}>8 \mathrm{~mm}$ & $123.41 \mathrm{~b}$ & $140.36 \mathrm{ab}$ & $156.51 \mathrm{a}$ & 9.551 & 0.037 \\
\hline
\end{tabular}




\section{Continued}

\begin{tabular}{cccccc}
\hline Total chewing & & & & & \\
Min/d & 775.00 & 766.25 & 772.92 & 28.549 & 0.926 \\
Min/kg of DM & $40.02 \mathrm{a}$ & $38.62 \mathrm{a}$ & $35.22 \mathrm{~b}$ & 1.896 & 0.004 \\
Min/kg of ADF & $217.02 \mathrm{a}$ & $215.30 \mathrm{a}$ & $159.18 \mathrm{~b}$ & 11.432 & $<0.001$ \\
Min/kg of NDF & $118.66 \mathrm{a}$ & $107.86 \mathrm{a}$ & $74.85 \mathrm{~b}$ & 5.981 & $<0.001$ \\
Min/kg of FNDF & $131.56 \mathrm{a}$ & $132.12 \mathrm{a}$ & $120.48 \mathrm{~b}$ & 6.351 & 0.019 \\
$\mathrm{Min} / \mathrm{kg}$ of peNDF $>4 \mathrm{~mm}$ & 160.56 & 169.72 & 176.50 & 10.466 & 0.427 \\
Min/kg of peNDF $>8 \mathrm{~mm}$ & $202.22 \mathrm{~b}$ & $227.00 \mathrm{ab}$ & $257.90 \mathrm{a}$ & 14.976 & 0.025 \\
\hline
\end{tabular}

Note: ${ }^{1} \mathrm{~N}$ control diet, $\mathrm{H}$ : corn stover high concentrates diet, $\mathrm{MH}$ : milled corn stover high concentrates diet. ${ }^{2} P>0.05$ indicating no significant effect, $P<0.05$ indicating significant effect, $0.05<P<0.10$ indicating a tendency of effect. Values within a row followed by different letters are significantly different (at $P=0.05$ ).

\subsection{Ruminal pH Changes}

As shown in Table 8, there were no significant differences in average $\mathrm{pH}$ among the treatments. The difference was also not significant in minimum $\mathrm{pH}$ and maximum $\mathrm{pH}$ between cows fed $\mathrm{N}$ and $\mathrm{MH}$. Even the proportion of concentrates was increased, pulverization of corn stalk maintained the average, maximum and minimum rumen $\mathrm{pH}$ levels as the control. For the area of $\mathrm{pH}<5.8$, the values of three treatments were $0.050,0.932$ and 0.158 , respectively. Although the values differed greatly, the differences among the treatments were not significant due to the large base values. The total time when $\mathrm{pH}<5.8$ reached $6.88 \mathrm{~h}$ for $\mathrm{H}$, the difference was also not significant among treatments due to the large base $(24 \mathrm{~h})$. Finally, the area and time of $\mathrm{pH}<5.8$ are within the acceptable range for all the treatments, and the difference was not significant. This also ensures the health of the cows in the test and prevents acidosis.

\section{Discussion}

\subsection{Diet Selection and Eating Behavior}

The selective eating behavior was most serious in cows fed the $\mathrm{H}$ diet. Speculate the roughage contained a large amount of untreated corn stalk, the palatability of the diet is poor. In the MH diet, corn stalk was made into powder, and mixed with the concentrates, which sufficiently reduced the cow's selective eating behavior.

Studies have shown that there is a positive correlation between dietary roughage level and chewing time [12] [13] [14]. In this trial, there was no significant difference in chewing time between the three groups of diets. This result may be caused by the preference of cows for the concentrates over low-quality roughage such as long fragments of corn stalk. In the experiment, we observed that there was a large amount of corn stalk remaining in $\mathrm{H}$ treatment after 12 hours of feeding. Therefore, the increase in the level of roughage in the diet may lead to an increase in the chewing time. The view that an increase in roughage level can lead to increased chewing time in dairy cows may not be applicable to low-quality roughage such as corn stalk. 
Table 8. Effects of the diets on ruminal $\mathrm{pH}$ in lactating Holstein cows.

\begin{tabular}{|c|c|c|c|c|c|}
\hline \multirow{2}{*}{ Item } & \multicolumn{3}{|c|}{ Treatment $^{1}$} & \multirow[b]{2}{*}{ SEM } & \multirow[b]{2}{*}{$P^{2}$-value } \\
\hline & $\mathrm{N}$ & $\mathrm{H}$ & $\mathrm{MH}$ & & \\
\hline \multicolumn{6}{|l|}{$\mathrm{pH}$} \\
\hline Mean $\mathrm{pH}$ & 6.25 & 5.90 & 6.08 & 0.065 & 0.241 \\
\hline Minimum $\mathrm{pH}$ & $5.76 \mathrm{a}$ & $5.43 \mathrm{~b}$ & $5.64 \mathrm{a}$ & 0.038 & 0.016 \\
\hline Maxmum pH & $6.75 \mathrm{a}$ & $6.29 \mathrm{~b}$ & $6.48 \mathrm{ab}$ & 0.075 & 0.030 \\
\hline Area under $\mathrm{pH} 5.8, \mathrm{pH} \times \mathrm{h} / \mathrm{d}$ & 0.05 & 0.93 & 0.16 & 0.311 & 0.385 \\
\hline Time under $\mathrm{pH} 5.8, \mathrm{~h} / \mathrm{d}$ & 0.61 & 6.89 & 2.08 & 2.043 & 0.340 \\
\hline$\%$ of daily time & 2.55 & 28.70 & 8.68 & 8.514 & 0.340 \\
\hline \multicolumn{6}{|l|}{ VFA } \\
\hline Total, $\mathrm{mmol} / \mathrm{L}$ & $101.02 \mathrm{a}$ & $91.34 \mathrm{ab}$ & $87.94 \mathrm{~b}$ & 4.676 & 0.047 \\
\hline Acetate & $64.76 a$ & $58.74 \mathrm{ab}$ & $57.75 b$ & 2.891 & 0.080 \\
\hline Propionate & $21.69 a$ & $19.70 \mathrm{ab}$ & $17.26 \mathrm{~b}$ & 1.678 & 0.117 \\
\hline Butyrate & $10.69 \mathrm{a}$ & $9.21 \mathrm{ab}$ & $9.54 \mathrm{~b}$ & 0.547 & 0.065 \\
\hline Isobutyric acid & 0.81 & 0.81 & 0.78 & 0.031 & 0.672 \\
\hline Valerate & $1.29 \mathrm{a}$ & $1.14 \mathrm{ab}$ & $0.97 \mathrm{~b}$ & 1.104 & 0.066 \\
\hline Isovaleric acid & 1.79 & 1.74 & 1.65 & 0.105 & 0.520 \\
\hline \multicolumn{6}{|l|}{$\mathrm{Mol} / 100 \mathrm{~mol}$} \\
\hline Acetate & 64.54 & 64.31 & 65.72 & 0.992 & 0.471 \\
\hline Propionate & 20.91 & 21.55 & 19.58 & 1.049 & 0.327 \\
\hline Butyrate & 10.71 & 10.07 & 10.82 & 0.342 & 0.115 \\
\hline Isobutyric acid & 0.82 & 0.90 & 0.90 & 0.036 & 0.086 \\
\hline Valerate & 1.25 & 1.25 & 1.10 & 0.073 & 0.203 \\
\hline Isovaleric acid & 1.77 & 1.93 & 1.89 & 0.069 & 0.235 \\
\hline A:P ratio & 3.24 & 3.09 & 3.40 & 0.193 & 0.432 \\
\hline NH3-N, mmol/L & $10.33 a$ & $7.63 \mathrm{~b}$ & $6.68 \mathrm{~b}$ & 0.855 & 0.005 \\
\hline
\end{tabular}

Note: ${ }^{1} \mathrm{~N}$ control diet, $\mathrm{H}$ : corn stover high concentrates diet, $\mathrm{MH}$ : milled corn stover high concentrates diet. ${ }^{2} P>0.05$ indicating no significant effect, $P<0.05$ indicating significant effect, $0.05<P<0.10$ indicating a tendency of effect. Values within a row followed by different letters are significantly different (at $P=0.05$ ).

In the relationship between feeding and ruminating time and the level of roughage in the diet. Researchers believe that roughage level has no influence on feeding and ruminating time [15] [16]. Second, studies on the relationship between chewing time and roughage sources, as well as the combined action of roughage sources and levels, are less similar. There are also relatively few studies on the sources of roughage and the combined effects of sources and levels on feeding and ruminating time. Also in this trial, the differences among the three groups of diets were similarly insignificant, regardless the feeding time and ruminating time. To sum up, further research is required to clarify the effects of roughage levels, sources and their combined effects on chewing, feeding and ru- 
minating time.

After reducing the size of corn stover, the chewing, feeding and ruminating time per kilogram of DM, ADF, NDF and FNDF were significantly lowered compared with that of the untreated corn stover diet. The unit feeding time of each component is mainly affected by time and feed intake. In the MH treatment, the chewing time per kilogram of DM or the like was lowered because of the increase in DMI. Sauvant et al. [17] showed that if DMI increases, the chewing time per kilogram of DM will decrease accordingly.

\subsection{Ruminal $\mathrm{pH}$}

Although the difference between the average ruminal $\mathrm{pH}$ was not significant, the maximum and the minimum $\mathrm{pH}$ were lower in the $\mathrm{H}$ group than in the $\mathrm{N}$ group.

The rumen $\mathrm{pH}$ mainly reflects the relationship between the ruminal acid elimination, some researchs showed that increasing the particle size of the roughage will increase ruminal $\mathrm{pH}$ because of the amount of saliva secretion increased [18]. However, some research results show dietary roughage can increase ruminal $\mathrm{pH}$ but the source, level and size of the roughage do not affect saliva secretion [18] [19]. While some authors think the effect of roughage sources on ruminal $\mathrm{pH}$ is mainly affected by the NDF structure of the roughage [8]. Similar results are also seen in other literature [10]. In the $\mathrm{N}$ and $\mathrm{MH}$ treatments of this test, the differences were not significant regardless of the average $\mathrm{pH}$ or the maximum and minimum $\mathrm{pH}$. From $\mathrm{pH}$ curve. There are two possible reasons for this. First, the alfalfa-dominated $\mathrm{N}$ diets has a faster NDF degradation rate, while corn stalk powder in $\mathrm{MH}$ had a much lower degradation rate than alfalfa. Second, the in $\mathrm{MH}$ pulverized corn stalk greatly reduced the selective behavior of dairy cows, and enhanced the activity and quantity of fibrolytic bacteria in the rumen. Therefore, the harm caused by high concentrate is offset to some extent. The time and area of $\mathrm{pH}<5.8$ in $\mathrm{H}$ treatment in this experiment were much larger than those in other treatments. It may cause rumen acidosis in dairy cows if the diet is used for long-term feeding.

\subsection{DMI and Apparent Digestibility}

DMI will decrease as the level of roughage increases. One of the main reasons is the filling power of roughage [16] [20]. In this experiment, $\mathrm{N}$ and $\mathrm{H}$ were very similar in DMI. The reason for this result may be that although $\mathrm{H}$ contained a higher proportion of concentrates, it also contained more low-quality roughage. Roughages have different NDF degradation rates and when the NDF degradation rate is high, the filling power in the rumen is reduced, thereby increasing the feed intake of the diet. In this experiment, $\mathrm{N}$ contained alfalfa as much as $20.7 \%$, but its DMI was similar to that of $\mathrm{H}$. The reason for this result may be due to the fact that alfalfa can produce large amounts of volatile fatty acids in the rumen. Studies also have shown that rumen osmotic pressure is involved in the regulation of rumen activity, while propionic acid among free fatty acids pro- 
motes glucagon and insulin release. On the relationship between roughage particles size and feed intake, Researchers found that reducing roughage size can increase DM and NDF intake [5] [21]. In this test, $\mathrm{MH}$ use pulverized corn stalk which might reduced the roughage filling power in the rumen, and reduced the selective behavior of the cow. These factors could explain the higher intake of DMI, NDF and ADF MH than that of the other two. Zebeli et al. [22] found in a meta-analysis of 64 studies that $14.9 \%$ is a critical value for peNDF $>8 \mathrm{~mm}$. If the peNDF $>8 \mathrm{~mm}$ content of the diet is above the critical value, the DMI will show a linear decrease. The content of peNDF $>8 \mathrm{~mm}$ in the $\mathrm{MH}$ group was $14.1 \%$, which was close to the critical value of $14.9 \%$ proposed by Zebeli et al. [22]. Moreover, the increase of peNDF $>8 \mathrm{~mm}$ content is accompanied by the decrease of DMI. At the same time, it seems that pulverized corn stalk dominated total mixed ration (TMR) is better at increasing FNDF intake than the corn stalk and alfalfa dominated TMR, but it has not achieved statistical significance, it presumably corn stalk being too short can lead to reduction in ruminating time, accelerating gastric emptying [23].

Studies have shown that reducing the roughage grain size can increase the feed apparent digestibility. In this trial, the DM digestibility of the MH diet was higher than the other two diets and it seems to confirm this view. In this test, corn stalk was pulverized, breaking the ester bond between cellulose, increasing the contact area between feed and rumen microorganisms. This resulted in higher DM and NDF digestibility in the MH group. Of course we not only consider the size of the roughage particle, the complex digestion process is also the basic conditions of animal physiological activities. A time-dependent fractional degradation rate that is accelerated over time can also happen in animals. The results of the in vitro and in situ model prove this hypothesis [24]. The digestion rate of feeds is a function of the time they remain in the digestive tract and changes in the digestion process can be described by dividing feed into a ruminal easily digested part, a slowly digested part and an indigestible part. These small difference could also have led to the results of the experiment. Further, while proper reduction of roughage size can increase the apparent digestibility of nutrients in the diet [21] [25], it also speeds up the passage of the diet through the rumen [7]. Therefore, due to the increase in the outflow rate, the nutrient digestibility of the diet is reduced, especially the concentrate. The differences in $\mathrm{CP}$ digestibility in this trial were not significant. However, numerically, the CP digestibility of the $\mathrm{MH}$ diet was lower than that of the $\mathrm{N}$ group. The lower apparent OM digestibility of the MH group also seems to confirm this view.

\subsection{Production Performance}

In this trial, milk production and $4 \% \mathrm{FCM}$ production by the $\mathrm{MH}$ treatment were significantly higher than those by the $\mathrm{N}$ treatment. This is due to the reduction in the level of the roughage, which led to the increase in the dietary energy concentration and the increase in DMI. This result is similar to previous 
studies [14] [26]. We noticed that there were also no differences in lactose production between the two groups, which is also in line with the difference in milk production between the two groups.

After reducing the roughage size, no significant difference was observed in milk fat production between cows fed $\mathrm{H}$ and $\mathrm{MH}$. This result is similar to other studies [18]. However, studies have shown that reducing the roughage particle size leads to a decrease in milk fat production [11]. This may be due to the different processing levels of dietary roughage.

The differences in milk protein production and milk protein content among the experimental groups were also not significant. This may be due to the similarity of FOM in each diet. There are of course also literatures showing that roughage length does not affect milk protein content [16] [18].

\section{Conclusion}

Rations with high-concentrates plus corn stalk powder can increase the milk yield under the premise of ensuring the rumen $\mathrm{pH}$ of normal dairy cows. The pulverization of corn stalk does not have an excessive effect on the digestibility of concentrates ingredients and make the cow feed intake significantly increased.

\section{Acknowledgements}

The study was financially supported by the earmarked fund for National Key $\mathrm{R}$ \& D program of China (2017YFD0500502), Cattle Agro-industry Technology Research System of Shandong Province (SDAIT-12-011-06), Natural Science Fund of China (31572427) (31372340), Key R \& D plan of shandong province and Taishan scholar project.

\section{Conflicts of Interest}

The authors declare no conflicts of interest regarding the publication of this paper.

\section{References}

[1] Weiss, W.P., St-Pierre, N.R., et al. (2009) Varying Type of Forage, Concentration of Metabolizable Protein, and Source of Carbohydrate Affects Nutrient Digestibility and Production by Dairy Cows. Journal of Dairy Science, 92, 5595-5606. https://doi.org/10.3168/jds.2009-2247

[2] Kendall, L.C., et al. (2009) Intake and Milk Production of Cows Fed Diets That Differed in Dietary Neutral Detergent Fiber and Neutral Detergent Fiber Digestibility. Journal of Dairy Science, 92, 313-323. https://doi.org/10.3168/jds.2008-1482

[3] Faverdin, P., Bareille, N., Heide, D., et al. (1999) Lipostatic Regulation of Feed Intake in Ruminants. Regulation of Feed Intake Zodiac Symposium, Wageningen, 22-24 April 1998, 89-102.

[4] Wang, B., Mao, S.Y., Yang, et al. (2014) Effects of Alfalfa and Cereal Straw as a Forage Source on Nutrient Digestibility and Lactation Performance in Lactating Dairy Cows. Journal of Dairy Science, 97, 7706-7715.

https://doi.org/10.3168/jds.2014-7961 
[5] Einarson, M.S., Plaizier, J.C. and Wittenberg, K.M. (2004) Effects of Barley Silage Chop Length on Productivity and Rumen Conditions of Lactating Dairy Cows Fed a Total Mixed Ration. Journal of Dairy Science, 87, 2987-2996. https://doi.org/10.3168/jds.S0022-0302(04)73430-X

[6] Calberry, J.M., Plaizier, J.C., Einarson, M.S., et al. (2003) Effects of Replacing Chopped Alfalfa Hay with Alfalfa Silage in a Total Mixed Ration on Production and Rumen Conditions of Lactating Dairy Cows. Journal of Dairy Science, 86, 3611-3619. https://doi.org/10.3168/jds.S0022-0302(03)73967-8

[7] Allen, M.S. (1997) Relationship between Fermentation Acid Production in the Rumen and the Requirement for Physically Effective Fiber. Journal of Dairy Science, 80, 1447-1462. https://doi.org/10.3168/jds.S0022-0302(97)76074-0

[8] Vargas-Bello-Pérez, E., Mustafa, A.F. and Seguin, P. (2008) Effects of Feeding Forage Soybean Silage on Milk Production, Nutrient Digestion, and Ruminal Fermentation of Lactating Dairy Cows. Journal of Dairy Science, 91, 229-235. https://doi.org/10.3168/jds.2007-0484

[9] Dhiman, T.R. and Satter, L.D. (1997) Yield Response of Dairy Cows Fed Different Proportions of Alfalfa Silage and Corn Silage. Journal of Dairy Science, 80, 20692082. https://doi.org/10.3168/jds.S0022-0302(97)76152-6

[10] Kleinschmit, D.H., Schingoethe, D.J., Hippen, A.R., et al. (2007) Dried Distillers Grains plus Solubles with Corn Silage or Alfalfa Hay as the Primary Forage Source in Dairy Cow Diets. Journal of Dairy Science, 90, 5587-5599. https://doi.org/10.3168/jds.2006-753

[11] Krause, K.M. and Combs, D.K. (2003) Effects of Forage Particle Size, Forage Source, and Grain Fermentability on Performance and Ruminal $\mathrm{pH}$ in Midlactation Cows. Journal of Dairy Science, 86, 1382-1397. https://doi.org/10.3168/jds.S0022-0302(03)73722-9

[12] Zebeli, Q., Tafaj, M., Weber, I., et al. (2007) Effects of Varying Dietary Forage Particle Size in Two Concentrate Levels on Chewing Activity, Ruminal Mat Characteristics, and Passage in Dairy Cows. Journal of Dairy Science, 90, 1929-1942. https://doi.org/10.3168/jds.2006-354

[13] Oba, M. and Allen, M.S. (2000) Effects of Brown Midrib 3 Mutation in Corn Silage on Productivity of Dairy Cows Fed Two Concentrations of Dietary Neutral Detergent Fiber: 2. Chewing Activities. Journal of Dairy Science, 83, 1342-1349. https://doi.org/10.3168/jds.S0022-0302(00)75001-6

[14] Lechartier, C. and Peyraud, J.L. (2010) The Effects of Forage Proportion and Rapidly Degradable Dry Matter from Concentrate on Ruminal Digestion in Dairy Cows Fed Corn Silage-Based Diets with Fixed Neutral Detergent Fiber and Starch Contents. Journal of Dairy Science, 93, 666-681. https://doi.org/10.3168/jds.2009-2349

[15] Beauchemin, K.A. (1991) Effects of Dietary Neutral Detergent Fiber Concentration and Alfalfa Hay Quality on Chewing, Rumen Function, and Milk Production of Dairy Cows. Journal of Dairy Science, 74, 3140-3151. https://doi.org/10.3168/jds.S0022-0302(91)78499-3

[16] Yang, W.Z. and Beauchemin, K.A. (2007) Altering Physically Effective Fiber Intake through Forage Proportion and Particle Length: Chewing and Ruminal pH. Journal of Dairy Science, 90, 2826-2838. https://doi.org/10.3168/jds.2007-0032

[17] Sauvant, D., Dulphy, J.P. and Michalet-Doreau, B. (1990) The Fibrosity Index of Ruminant Feed and Diet.

[18] Yang, W.Z. and Beauchemin, K.A. (2005) Effects of Physically Effective Fiber on Digestion and Milk Production by Dairy Cows Fed Diets Based on Corn Silage. 
Journal of Dairy Science, 88, 1090-1098. https://doi.org/10.3168/jds.S0022-0302(05)72776-4

[19] Jiang, F.G., Lin, X.Y., Yan, Z.G., et al. (2017) Effect of Dietary Roughage Level on Chewing Activity, Ruminal pH, and Saliva Secretion in Lactating Holstein Cows. Journal of Dairy Science, 100, 2660-2671. https://doi.org/10.3168/jds.2016-11559

[20] Moorby, J.M., Dewhurst, R.J., Evans, R.T., et al. (2006) Effects of Dairy Cow Diet Forage Proportion on Duodenal Nutrient Supply and Urinary Purine Derivative Excretion. Journal of Dairy Science, 89, 3552-3562. https://doi.org/10.3168/jds.S0022-0302(06)72395-5

[21] Kononoff, P.J. and Heinrichs, A.J. (2003) The Effect of Corn Silage Particle Size and Cottonseed Hulls on Cows in Early Lactation. Journal of Dairy Science, 86, 24382451. https://doi.org/10.3168/jds.S0022-0302(03)73838-7

[22] Zebeli, Q., Mansmann, D., Ametaj, B.N., et al. (2010) A Model to Optimise the Requirements of Lactating Dairy Cows for Physically Effective Neutral Detergent Fibre. Archives of Animal Nutrition, 64, 265-278. https://doi.org/10.1080/1745039X.2010.486603

[23] Shi, H.T., Cao, Z.J. and Li, S.L. (2012) Development and Utilization of the Nutritional Value of Corn Stalks-Cheap Resources That Are Not Fully Exploited. Chinese Cows, 17, 3-11.

[24] France, J., Thornley, J.H.M., Lopez, S., et al. (1990) On the Two Compartment Model for Estimating the Rate and Extent of Feed Degradation in the Rumen. Journal of Theoretical Biology, 146, 269-287. https://doi.org/10.1016/S0022-5193(05)80139-0

[25] Maulfair, D.D., Fustini, M. and Heinrichs, A.J. (2011) Effect of Varying Total Mixed Ration Particle Size on Rumen Digesta and Fecal Particle Size and Digestibility in Lactating Dairy Cows. Journal of Dairy Science, 94, 3527-3536. https://doi.org/10.3168/jds.2010-3718

[26] Yang, W.Z. and Beauchemin, K.A. (2009) Increasing Physically Effective Fiber Content of Dairy Cow Diets through Forage Proportion versus Forage Chop Length: Chewing and Ruminal pH. Journal of Dairy Science, 92, 1603-1615. https://doi.org/10.3168/jds.2008-1379 